\title{
THE EFFECTIVENESS OF CHITOSAN ON THE TOXIGENIC STAPH. AUREUS IN YOGHURT
}

\author{
MANAL M. AMIN
}

Animal health research institute

Email: manalamin727@yahoo.com

\section{ABESTRACT}

Received at: $24 / 12 / 2013$

Chitosan and its derivatives, which are known to possess multiple functional properties, have attracted considerable interest due to their biological activities and potential applications in the pharmaceutical, food, agricultural and environmental industries. Many researchers have focused on chitosan as a potential source of bioactive material in the past few decades. This study focuses

Accepted: 13/2/2014 on the antibacterial and antitoxin activity of chitosan against $S$. aureus and it's enterotoxin type C. Chitosan inhibit growth of $S$. aureus which inoculated at $10^{5}$ in yoghurt at $5^{\text {th }}$ day in all trails at different concentrations (conc.) $(0.5,1$ and $2 \%)$. Enterotoxin type $\mathrm{C}$ inhibited at $10^{\text {th }}$ day at $0.5 \%$ conc. in yoghurt. While, at $1 \%$ and $2 \%$ conc. of chitosan complete inhibition of toxin occurred at $6^{\text {th }}$ day. Positive control trial, the toxin still detected until the end of the experiment. Chitosan haven't flavor, but have $55 \%$ of consumers were strongly agree to addition of $0.5 \%$ chitosan, $40 \%$ of consumers to $1 \%$ chitosan and $20 \%$ for $2 \%$ chitosan. The conc. of chitosan at 1 and $2 \%$ have the same antibacterial and antitoxin effect, so this study advised to use chitosan at $1 \%$ conc. to reduce the public health hazards of $S$. aureus and it's enterotoxin.

Keywords: Chitosan, Staphylo coccus aureus, Toxin type C, Yoghurt.

\section{INTRODUCTION}

Chitosan is a natural nontoxic biopolymer produced by the deacetylation of chitin, a major component of the shells of crustaceans such as crab, shrimp, and crawfish. Currently, chitosan has received extensive attention for its variable applications in the biomedical, food, and chemical industries (Arai et al., 1968 and Kumar et al., 2004).

Recent research has focused on the possibility of developing chitosan as a natural disinfectant (Harish Prashanth et al., 2005). It has also been used in the removal of waterborne pathogens in waste water and as a food preservative by applying a coat on the exterior of vegetable and fruit products (Cummings et al., 2009).

Yoghurt is one of the best known food products that may contain probiotics and is currently increasing supplementation with prebiotics, a type of fiber that stimulates the growth of specific bacteria in the gut (Laparra et al., 2008). Synbiotic is a new concept to describe this kind of product and is popular among dairy manufactures in Europe (Yeung et al., 2005). Because chitosan is an animal-origin carbohydrate polymer, which is included in the definition, it is being used as a new source of dietary fiber helping to meet consumer requirements all over the world that are increasingly interested in products high in dietary fiber (Harish Prashanth and Tharanathan, 2007 and Elleuch et al., 2011).

On the other hand, S. aureus is found as a commensal organism on the squamous epithelium of the anterior nares up to $20 \%$ of the population at any one time, however, it has been estimated that $S$. aureus can transiently colonize up to $60 \%$ of the human population (Foster, 2004). The pathogenicity of $S$. aureus is determined by the production of toxins, these toxins can be harmful to the host and cause skin diseases and other complications, such as endocarditis, meningitis as well as toxic shock syndrome [TSS] (Mims et al., 2004). Likewise, S. aureus can cause a wide range of infections ranging from minor skin abscesses to more serious invasive diseases. S. aureus can produce an enterotoxin that is the causative agent of $S$. aureus gastroenteritis. This gastroenteritis is self-limiting, characterized by vomiting and diarrhea one to six hours after ingestion of the toxin with recovery in eight to 24 hours. Symptoms include nausea, vomiting, diarrhea, and major abdominal pain (Becker et al., 2003). S. aureus commonly causes boils, carbuncles, furuncles and impetigo, but after gaining access to the blood, may also be a major cause of endocarditis, osteomyelitis, pneumonia, TSS and septicemia (Lowy, 1998). Chitosan possesses some ideal properties of 
polymeric carriers for nanoparticles such as biocompatible, biodegradable, nontoxic, and inexpensive. These properties render chitosan a very attractive material as a drug delivery carrier. In the last two decades, chitosan nanoparticles have been extensively developed and explored for pharmaceutical applications (Roberts, 1992). Furthermore, Chitosan has the ability to inhibit entertoxin production by $S$. aureus (Patrick, 2007) so, in this study the effect of chitosan on $S$. aureus count and enterotoxin type $\mathrm{C}$ inoculated in yoghurt was examined.

\section{MATERIALS and METHODS}

\section{1- Bacterial suspension inoculation:}

Reference strain of $S$. aureus was used, which previously have demonstrated their ability for enterotoxin type $\mathrm{C}$ production (reference strain from Animal Health Research Institute, Giza with code NCTC 7447 / ATCC 6538). S. aureus was grown in staph selective broth for $24-48 \mathrm{~h}$ at $37{ }^{\circ} \mathrm{C}$. Then the suspension was adjusted to the turbidity of a 0.5 McFarland standard by adding sterile saline to achieve a strain concentration of approximately $1 \times 10^{5}$ colony forming units /ml (Gentilini et al., 2000).

2- Detection of enterotoxin type $C$ concentration in the inoculated broth by ELISA (Ewald, 1988):

Accurately, RIDASCREEN set C (Art No.: R4101, R-Biopharm AG, Darmstadt, Germany) is an enzyme immunoassay for the determination of S.aureus enterotoxin $\mathrm{C}$ by using its definite kits.

According to the test kit manual, a loopful of the culture was mixed in sterile buffer saline and then shaken for 15 minutes. After centrifugation for 10 minutes at 3500 r.p.m, sterile filtration of the supernatant was applied. An aliquot $(100 \mu \mathrm{l}$ per kit well) of this solution was used in the test. Further, the last well was represented as positive control. They were mixed gently and incubated for one hour at room temperature $\left(20-25^{\circ} \mathrm{C}\right)$ in the dark.

The liquid was dumped out of the wells into a sink to remove all of the remaining liquid from the wells. Therefore, the wells were then filled with $250 \mu \mathrm{l}$ of washing buffer and the liquid was poured out again. The washing step was repeated 3 more times to remove the unbound conjugate.

Subsequently, $100 \mu \mathrm{l}$ of enzyme conjugate were added to each well and incubated for one hour at room temperature in the dark after mixing gently. The liquid was dumped out of the wells into a sink and the wells were each filled with $250 \mu \mathrm{l}$ of the washing buffer. The liquid was poured out again and the wells were emptied to remove all of the remaining liquid. The washing step was repeated 3 more times again.

Afterwards, $50 \mu \mathrm{l}$ of substrate and $250 \mu \mathrm{l}$ of chromogen solutions were added to each well. The solutions were mixed gently and incubated for 30 minutes at room temperature in the dark. Finally, 100 $\mu \mathrm{l}$ of the stop solution $\left(1 \mathrm{M} \mathrm{H}_{2} \mathrm{SO}_{4}\right)$ were added to each well with gentler mixing.

By using ELISA, the absorbance was measured at $450 \mathrm{~nm}$ in an ELISA plate reader (ELX800, BioTek Instruments, Bad Friedrichshall, Germany).

\section{3- The effectiveness of chitosan on the toxigenic $S$. aureus in yoghurt:}

Pasteurized milk was purchased from a retail market and heated to $45^{\circ} \mathrm{C}$ and inoculated with $2 \%$ yoghurt culture. One $\mathrm{ml}$ of each strain suspension (which prepared as before) mixed with $100 \mathrm{ml}$ of prepared milk and divided into 4 suitable sterile jars, chitosan was added to 3 parts at concentrations of $0.5,1$ and 2\%, 1 part without chitosan as a positive control, incubated at $40{ }^{\circ} \mathrm{C}$ until curdling. Control jar (free from strain suspension and chitosan as a negative control) was also incubated. The jars were stored at refrigerator temperature $\left(5 \pm 2{ }^{\circ} \mathrm{C}\right)$. The inoculated jars were examined bacteriologically for the count of $S$. aureus using Baird-Parker media $\left(37^{\circ} \mathrm{C}\right.$ for $\left.24-48 \mathrm{~h}\right)$ (I.C.M.S.F., 1978) and for presence of enterotoxin type C by ELISA (Ewald, 1988) after curdling (at time zero) and, every 2 days until the end of the storage period (14 days) and detected by the $\mathrm{pH}$ was measured in the control jars by using $\mathrm{pH}$ meter.

\section{4- Sensory evaluation:}

Control yoghurt jars (free from $S$. aureus but inoculated with chitosan at concentrations of $0,0.5,1$ and $2 \%$ ) were prepared as previously mentioned and each was subjected to the previous treatments. Thirty consumers were selected in teams of different ages, sex (20 females and 10 males), and education to taste the trials. The perception of consumers toward samples with various conc. of fennel honey was studied with respect to two different attributes (flavor and palatability). The level of agreement was scored as strongly agree (SA), agree (A), disagree (D), and strongly disagree (SD) according to Nelson and Torut (1981). 


\section{RESULTS}

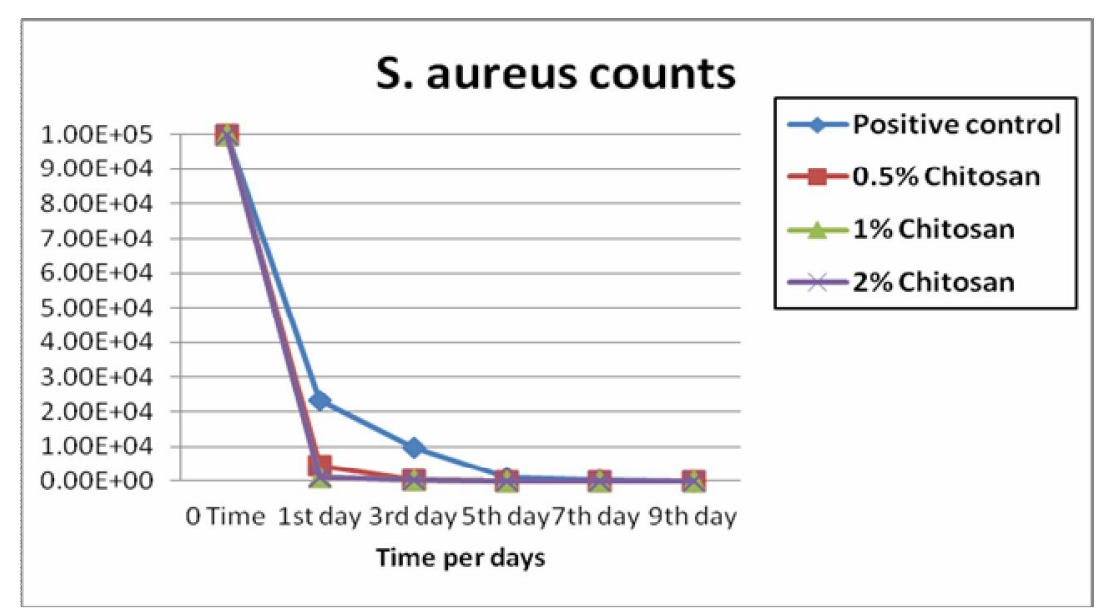

Fig.1: Effect of chitosan on $S$. aureus counts inoculated in yoghurt.

Table1: Effect of chitosan on enterotoxin type C produced by S. aureus inoculated in yoghurt.

\begin{tabular}{|c|c|c|c|c|c|}
\hline \multirow{2}{*}{$\begin{array}{c}\text { Treatment } \\
\text { Storage time }\end{array}$} & \multirow{2}{*}{-ve Control } & \multirow{2}{*}{ Control +ve } & \multicolumn{3}{|c|}{ Chitosan concentrations } \\
\hline & & & $0.5 \%$ & $1 \%$ & $2 \%$ \\
\hline Zero time & ------ & 60 & 60 & 60 & 60 \\
\hline 2 days & ------ & 60 & 55 & 40 & 40 \\
\hline 4 days & ------ & 60 & 30 & 10 & 5 \\
\hline 6 days & ------ & 60 & 20 & ------ & ------ \\
\hline 8 days & ------ & 60 & 5 & ------ & ------ \\
\hline 10 days & ------ & 60 & ------ & ------ & ------ \\
\hline
\end{tabular}

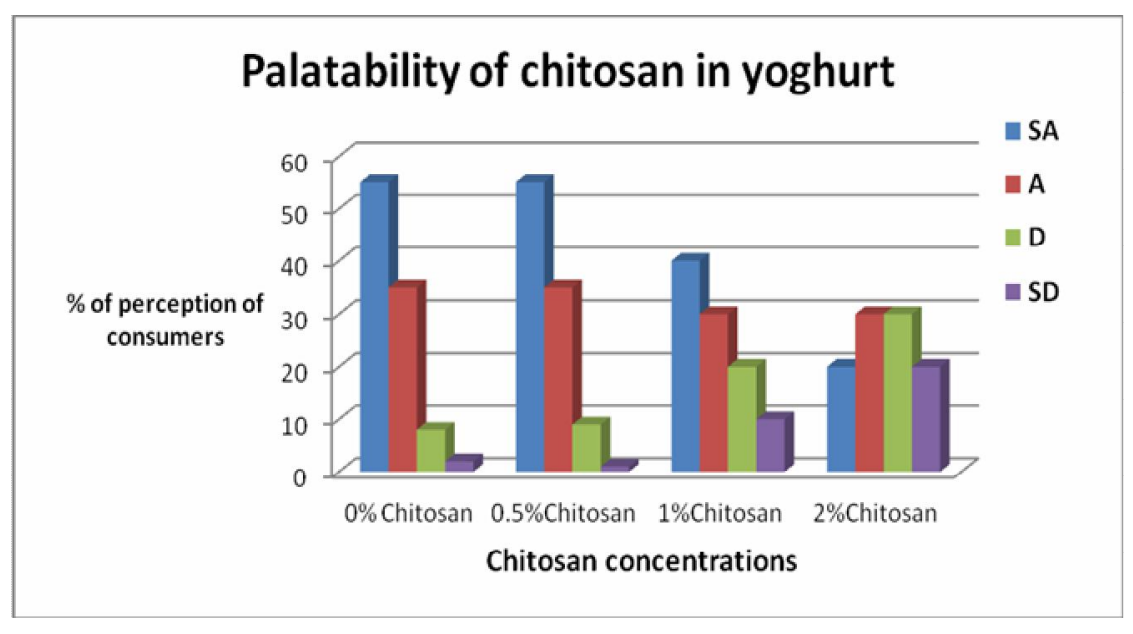

Fig.2: Palatability of chitosan in yoghurt.

* strongly agree (SA), agree (A), disagree (D), and strongly disagree (SD) 


\section{DISCUSSION}

S. aureus can multiply rapidly in food held at room temperature and the toxin can be produced by the microorganism growing in the food. This toxin is called an enterotoxin because it causes gastroenteritis or inflammation of the lining of the intestinal tract. Thorough cooking destroys the $S$. aureus bacteria, but the toxin is very resistant to heat, refrigeration, and freezing. The toxin is produced when the Staphylococcus aureus populations exceed $10^{6} \mathrm{CFU} /$ gram of food. Less than 1.0 microgram of the toxin in food will produce staphylococcal intoxication symptoms.

Chitosan is the most important chitin derivative in terms of application (Salmabi and Seema, 2013).

Chitosan has attracted considerable interest because of its unique combination of properties, such as biocompatibility, biodegradability, metal complication and antibacterial activity. Chitosan has a variety of current and potential applications in various fields, for example, biotechnology (Mao et al., 2001), pharmaceutics (Illum, 1998), wastewater treatment, cosmetics (Majet and Kumar, 2000), and food science (Chien et al., 2007). The antibacterial activity of chitosan has been widely explored (Hong et al., 2002; Tsai et al., 2004 and Liu et al., 2006). As shown in Fig. 1 chitosan markedly inhibited the growth of $S$. aureus in yoghurt at $5^{\text {th }}$ day in all trails. The activity increased with increasing concentration of chitosan. While, in positive control S. aureusstill in high concentration until $3^{\text {rd }}$ day and inhibited at $7^{\text {th }}$ day and that may be returned to increase the acidity of yoghurt and Staph. organisms are the most sensitive bacterial species to acidity (Bergdoll and Lee Wong, 2006). Valero et al. (2009) recorded that for a cocktail of five enterotoxigenic $\mathrm{S}$. aureusisolates growth has been recorded at $\mathrm{pH} 4.5$. Chitosan showed significant antibacterial activity against $S$. aureus and that returned to Chitosan shows great potential in developing into a biocompatible antibiotic. Chitosan with a high molecular weight (500KD-1000KD) and maximum degree of de-acetylation is expected to show enhanced antimicrobial activity even at lower concentrations (Rhodes and Roller, 2000 and Raafat, 2008), theorized that a mild degradation of chitosan enhances its antimicrobial action, where as highly degraded chitosan displayed no antimicrobial action (Salmabi and Seema, 2013). Monarul et al. (2011) reported that many hypotheses have been proposed to elucidate the mechanism of antibacterial activity of chitosan. Chitosan contains three types of reactive functional groups, an amino/acetamido group as well as, both primary and secondary hydroxyl groups at the C-2, C-3 and C-6 positions, respectively. This electrostatic interaction results in twofold interference:i) by promoting changes in the properties of membrane wall permeability, thus incite internal osmotic imbalances and consequently restrain the growth of microorganisms (Shahidi et al., 1999) and ii) by the hydrolysis of the peptidoglycans in the microorganism wall, leading to the leakage of intracellular electrolytes such as potassium ions and other low molecular weight proteinaceous constituents (e.g. proteins, nucleic acids, glucose, and lactate dehydrogenase) (Papineau et al., 1991 and Chen et al., 1998).

In this study the same results are in agree with Chung and Chen, (2008); Másson et al. (2008) and Raafat et al. (2008). likewise, Patrick (2007) reported that chitosan at 3.5 and $7.0 \mathrm{mg} / \mathrm{ml}$ (final concentrations) was bactericidal for $S$. aureus.

Chitosan have antitoxic effect against enterotoxin which produced by $S$. aureus and that may returned to it's a polysaccharide comprised of repeating units of glucosamine. The mechanism underlying its growth and toxin-inhibitory effects remains unknown, but may be related to its strong charge (Patrick, 2007). The polymeric size and charge suggest the agent may inhibit exotoxin production by effects on the microbial surface and thus by interfering with signal transduction. (Projan et al., 1994).

In this study, chitosan inhibited enterotoxin type $\mathrm{C}$ at $10^{\text {th }}$ day at $0.5 \%$ conc. in yoghurt. While, at 1 and $2 \%$ conc. of chitosan complete inhibition of toxin occurred at $6^{\text {th }}$ day. Positive control trial, the toxin still detected until the end of experiment at the same concentration $(60 \mathrm{~nm} / \mathrm{ml})$ and that may returned to that the optimum $\mathrm{pH}$ for $S$. aureus producing enterotoxin ranged between $\mathrm{pH} 5.7$ and 4.9 under aerobic conditions. It was noted that growth occurred in the absence of enterotoxin production under some conditions. No culture was able to produce enterotoxin at a $\mathrm{pH}$ less than 5.7 under anaerobic conditions (Paulin et al., 2012). Similar results were obtained for three Staph. enterotoxin type B, and one for type C-producing strains. However a strain producing type $\mathrm{E}$ formed enterotoxin weakly at $\mathrm{pH}$ 4.8 (Genigeorgis et al., 1971).

These results is in agreement with Yarwood et al. (2001); Novick (2003); Yarwood and Schlievert (2003); Pragman and Schlievert (2004) and Patrick (2007).

Also, Burkatovskaya et al. (2006) shown that chitosan, an agent that could be added to wound dressings, inhibited both bacterial growth and exotoxin production in vitro and prevented Toxic Shock Syndrome (TSS) and necrotizing fasciitis in rabbit models. It has long been known that chitosan inhibits the growth of gram positive and gramnegative bacteria, with greater antimicrobial activity against gram-positive agents (Takai et al., 2002 and Rabea et al., 2003). Also, Mendel and Vijay (2010) reviewed that chitosans are reported to exhibit numerous health-related beneficial effects, including strong antitoxin and antioxidative activities in 
foods. A special need exists to develop a better understanding of the role of chitosans in ameliorating foodborne illness. To contribute to this effort, this overview surveys and interprets our present knowledge of the chemistry and antimicrobial activities of chitosan in solution, as powders, and in edible films and coating against foodborne pathogens, spoilage bacteria, and pathogenic viruses and fungi in several food categories. They suggested that lowmolecular-weight chitosans at a pH below 6.0 presents optimal conditions for achieving desirable antimicrobial, antitoxin and antioxidativepreservative effects in liquid and solid foods.

Regarding, the perception of consumers toward samples subjected to various chitosan conc. with respect to two different attributes (flavor and palatability), $55 \%$ of consumers were strongly agree to addition of $0.5 \%$ chitosan and $40 \%$ of consumers to $1 \%$ chitosan (Fig. 2). Generally, $1 \%$ chitosan conc. considered the most preferable additives in all samples than $2 \%$ chitosan conc. Chitosan have no flavor effect when added to yoghurt at different concentrations.

\section{REFERENCES}

Arai, K.; Minumari, K. and Fujita, T. (1968): On the toxicity of chitosan. Bull. Tokai Reg. Fish. Res. $L a b$., 56: 889-892.

Becker (2003): "Prevalence of Genes Encoding Pyrogenic Toxin Superantigens and Exfoliative Toxins among Strains of Staphylococcus aureus Isolated from Blood and Nasal Specimens", J. Clin. Microbiol.; 41(4): 1434-1439.

Bergdoll, M.S. and Lee Wong, A.C. (2006): Staphylococcal intoxications. In: Foodborne Infections and Intoxications, (Eds) H. P. Reimann and D. O. Cliver, 523-562. Elsevier.

Burkatovskaya, M.; Tegos, G.P.; Swietlik, E.; Demidova, T.N.; Castano, A.P. and Hamblin, M.R. (2006): Use of chitosan bandage to prevent fatal infections developing from highly contaminated wounds in mice. Biomaterials 27: 4157-4164.

Chen, C.S.; Liau, W.Y. and Tsai, G.J. (1998): Antibacterial effects of N-sulfonated and Nsulfobenzoyl chitosan and application to oyster preservation. J. Food Prot., 61: 1124-1128.

Chien, P.J.; Seu, F. and Yang, F.H. (2007): Effects of edible chitosan coating on quality and shelf life of sliced mango fruit. J. Food Eng. 78: 225-229.

Chung, Y.C. and Chen, C.Y. (2008): Antibacterial characteristics and activity of acid-soluble chitosan. Bioresource Technol., 99: 28062814.

Cummings, T.J.; Mann, J.; Nishida, C. and Vorster, H. (2009): Dietary fibre: An agreed definition. Lancet, 373: 365-366.
Elleuch, M.; Bedigian, D.; Roiseux, O.; Besbes, S.; Blecker, C. and Attia, H. (2011): Dietary fibre and fibre-rich by-products of food processing: Characterization, technological functionality and commercial applications: A review. Food Chem., 124: 411-421.

Ewald, S. (1988): Evaluation of enzyme-linked immunusorbant assay (ELISA) for detection of staphylococcal enterotoxin in foods. Inter. J. Food Microbiology, 6 (2): 141-153.

Foster, T.J. (2004): The Staphylococci aureus "superbug". J. Clin. Invest. 2004; 114: 1693-1696.

Genigeorgis, C.; Foda, M.S.; Mantis, A. and Sadler, $W . W$. (1971): Effect of sodium chloride and $\mathrm{pH}$ on enterotoxin $\mathrm{C}$ production. Applied and Environmental Microbiology, 21: 862-866.

Gentilini, E.; Denamiel, E.; Llorente, P.; Godaly, S.; Rebulto, M. and De Gregorio, O. (2000): Antimicrobial susceptibility of $S$. aureus isolated from bovine mastitis in Argentina. J. Dairy Sci., 83: 1224-1227.

Harish Prashanth, K.V.; Lakshman, K.; Shamala, T.R. and Tharanathan, R.N. (2005): Biodegradation of chitosan-graftpolymethylmethacrylate films. Int. Biodeterior. Biodegrad., 56: 115-120.

Harish Prashanth, K.V. and Tharanathan, R.N. (2007): Chitin/chitosan: Modifications and their unlimited application potential. Trends Food Sci. Technol., 18: 117-131.

Hong, K.N.; Park, N.Y.; Lee, S.H. and Meyers, S.P. (2002): Antibacterial activity of chitosans and chitosan oligomers with different molecular weights. Int. J. Food Microbiol. 74(1-2): 65-72

I.C.M.S.F. (International Commission on Microbiological Specification for Foods) (1978): Microorganisms in Foods, Vol. I: Their significance and methods of enumeration. $2^{\text {nd }}$ ed. Univ. Toronto Press, Toronto Buffalo, London.

Illum, L. (1998): Chitosan and its use as a pharmaceutical excipient. Pharm. Res. 15: 1326-1331.

Kumar, M.N.; Muzzarelli, R.A.; Muzzarelli, C.; Sashiwa, H. and Domb, A.J. (2004): Chitosan chemistry and pharmaceutical perspectives. Chem. Rev., 104: 6017-6084.

Laparra, J.M.; Tako, E.; Glahn, R.P. and Miller, D.D. (2008): Supplemental inulin does not enhance iron bioavailability to Caco-2 cells from milk- or soy-based, probiotic-containing, yoghurts but incubation at $37{ }^{\circ} \mathrm{C}$ does. Food Chem., 109: 122-128.

Liu, N.; Chen, X.G.; Park, H.J.; Liu, C.G.; Liu, C.S.; Meng, X.H. and Yu, L.J. (2006): Effect of MW and concentration of chitosan on antibacterial activity of Escherichia coli. Carbohydr. Polym. 64: 60-65. 
Lowy, F.D. (1998): S. aureus infections. New England Journal of Medicine. 339: 520-532.

Majet, N.V. and Kumar, R. (2000): A review of chitin and chitosan applications. React. Funct. Polym. 46(1): 1-27.

Mao, H.Q.; Roy, K.; Troung-Le, V.L.; Janes, K.A.; Lin, K.Y.; Wang, Y.; August, J.T. and Leong, $K . W$. (2001): Chitosan-DNA nanoparticles as gene carrier: Synthesis, characterization and transfection efficiency. J. Control Release, 70: 399-421.

Másson, M.; Holappa, J.; Hjálmarsdóttir, M.; Rúnarsson, Ö.V.; Nevalainen, T. and Järvinen, T. (2008): Synthesis of novel quaternary chitosan derivatives via N-Chloroacyl-6-Otriphenylmethylchitosans. Carbohyd. Polym., 74: 566-571.

Mendel, J.F. and Vijay, K. (2010): Review of antimicrobial and antioxidative activities of chitosans in food. J. of Food Prot. (9): 1596-1773.

Mims, C.; Dockrell, H.M. and Goering, R.V. (2004): Medical Microbiology. $3^{\text {rd }}$ ed. Elsevier Mosby, Edinburgh, United Kingdom. 585-586.

Monarul, Md.; Shah, Md.M.; Khandaker Rayhan Mahbuba and Zahurul Haquea, Md. (2011): Antibacterial activity of crab-chitosan against S. aureus and Escherichia coli. J. Adv. Scient. Res., 2(4): 63-66

Nelson, J.A. and Torut, G.M. (1981): Judging Dairy Products, $4^{\text {th }}$ ed., revised. Westport, CT: The AVC.

Novick, R.P. (2003): Autoinduction and signal transduction in the regulation of staphylococcal virulence. Mol. Microbiol. 48: 1429-1449.

Papineau, A.M.; Hoover, D.G.; Knorr, D. and Farkas, D.F. (1991): Biological effects of high hydrostatic pressure on food microorganisms. Food Biotechnol., 5: 45-57.

Patrick, M.S. (2007): Chitosan malate inhibits growth and exotoxin production of toxic shock syndrome-inducing $S$. aureus strains and group A Streptococci. Antimicrobial agents and Chemotherapy j., 51(9): 3056-3062.

Paulin, S.; Beverley, H. and John, A.H. (2012): Factors influencing staphylococcal enterotoxin production in dairy products. Prepared for the Ministry for Primary Industries. Growing and protecting New Zealand. Copyright, 2012 Ministry for Primary Industries. http://www.mpi.govt.nz/newsresources/publications. aspx.

Pragman, A.A. and Schlievert, P.M. (2004): Virulence regulation in $S$. aureus: the need for in vivo analysis of virulence factor regulation. FEMS Immunol. Med. Microbiol. 42: 147-154.

Projan, S.J.; Brown-Skrobot, S.; Schlievert, P.M.; Vandenesch, F. and Novick, R.P. (1994):
Glycerol monolaurate inhibits the production of beta-lactamase, toxic shock toxin-1, and other staphylococcal exoproteins by interfering with signal transduction. J. Bacteriol. 176: 4204-4209.

Raafat, D. (2008): Chitosan as an antimicrobial agent: Modes of action and resistance mechanisms. Dissertation, Uni. of Bonn.

Raafat, D.; Von Bargen, K.; Haas, A. and Sahl, H.G. (2008): Insights into the mode of action of chitosan as an antibacterial compound. Appl. Environ. Microbiol., 74: 3764-3773.

Rabea, E.I.; Badawy, M.E.; Stevens, C.V.; Smagghe, G. and Steurbaut, W. (2003): Chitosan as antimicrobial agent: Applications and mode of action. Biomacromolecules 4: 1457-1465.

Rhodes, J. and Roller, S. (2000): Antimicrobial actions of degraded and native chitosan against spoilage organisms in laboratory media and foods. Appl. Environ. Microbiol. 66: 80-86.

Roberts, G.A.F. (1992): Chitin Chemistry. Macmillan Press, London, UK, pp. 55-58.

Salmabi, K.A and Seema, P.N. (2013): Antibacterial potential of chitosan on pathogenic gram positive cocci. Advanced Bio Tech. vol.12 issue $10 \quad 1$ april 2013. www. advancedbiotech.in.

Shahidi, F.; Arachchi, J. and Jeon, Y.J. (1999): Influence of chitosan addition on quality properties of vacuum-packaged pork sausagesTrends Food Sci. Technol.; 10: 37-51.

Takai, K.; Ohtsuka, T.; Senda, Y.; Nakao, M.; Yamamoto, K.; Matsuoka, J. and Hirai, Y. (2002): Antibacterial properties of antimicrobial-finished textile products. Microbiol. Immunol. 46: 75-81.

Tsai, G.J.; Zhang, S.L. and Shieh, P.L. (2004): Antimicrobial activity of a low-molecularweight chitosan obtained from cellulase digestion of chitosan. J. Food Prot. 67: 396-398

Valero, A.; Pérez-Rodríguez, F.; Carrasco, E.; Fuentes-Alventosa, J.M.; García-Gimeno, R.M. and Zurera, G. (2009): Modelling the growth boundaries of $S$. aureus: Effect of temperature, $\mathrm{pH}$ and water activity. Int. J. of Food Microbiol., 133:186-194.

Yarwood, J.M.; McCormick, J.K. and Schlievert, P.M. (2001): Identification of a novel twocomponent regulatory system that acts in global regulation of virulence factors of $S$. aureus. J. Bacteriol. 183: 1113-1123.

Yarwood, J.M. and Schlievert, P.M. (2003): Quorum sensing in staphylococcus infections. J. Clin. Investig. 112: 1620-1625.

Yeung, C.K.; Glahn, R.P.; Welch, R.M. and Miller, D.D. (2005): Prebiotics and iron bioavailability-Is there a connection? J. Food Sci., 70: 88-92. 


\section{مدى فاعلية الثيتوزان على المكور العنقودى الذهبي المفرز للسموم في الزبادي

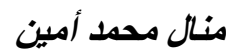

Email: Email: manalamin727@yahoo.com

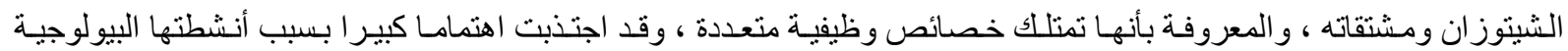

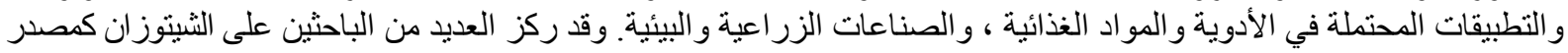

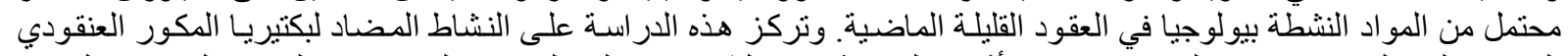

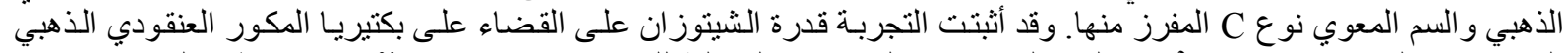

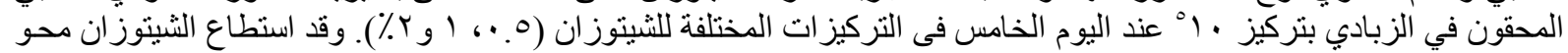

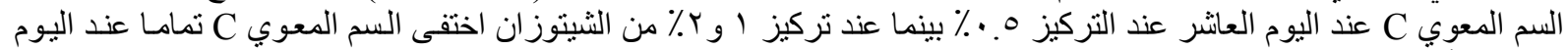

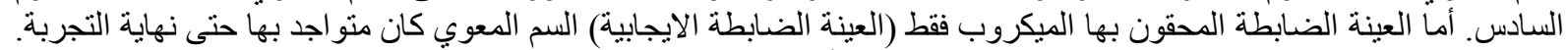

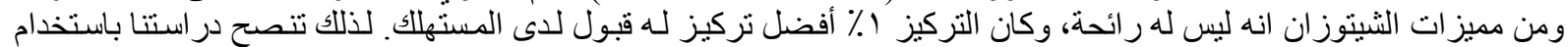

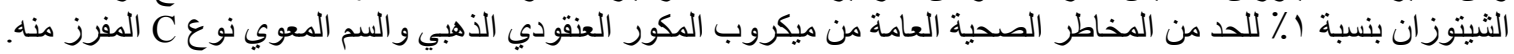

